\title{
Production of lettuce in NFT hydroponic system at different planting seasons and irrigation regimes
}

\author{
Cláudio Silva Soares ${ }^{1}$, Alde Cleber Silva de Lima ${ }^{1}$, Jeneilson Alves da Silva ${ }^{1}$, Marina Suenia de Araújo Vilar ${ }^{2}$, \\ André Luiz Pereira da Silva ${ }^{3}$, Joaquim Alves de Lima Junior ${ }^{4}$, José Félix de Brito Neto ${ }^{1}$ \\ ${ }^{1}$ Department of Soil Fertility, Universidade Estadual da Paraíba - UEPB, Lagoa Seca, Paraíba, Brazil \\ ${ }^{2}$ Department of medical science - UNIFACISA, Campina Grande, Paraíba, Brazil \\ ${ }^{3}$ Department of Plant Production, Universidade Estadual Paulista - UNESP, Jaboticabal, São Paulo, Brazil \\ ${ }^{4}$ Department of Plant Production, Universidade Federal Rural da Amazônia - UFRA, Capanema, Pará, Brazil
}

*Corresponding author: andreengagronomo@gmail.com

Abstract

Hydroponics has drawn huge interests by Brazilians in semi-arid regions due to the lack of water and fertilizer use. The objective of this study was to evaluate the growth and yield of lettuce cultivars in the hydroponic system in two planting seasons and different irrigation regimes. The research was carried out in Campus II / UEPB and followed a $2 \times 6 \times 3$ factorial scheme in randomized blocks, represented by two planting seasons (the summer and the winter), six lettuce cultivars (Elba, Great Lakes, Mimosa Rose, Simpson, American, Cristina), three irrigation regimes (15 $\mathrm{min}, 30 \mathrm{~min}, 45 \mathrm{~min}$ ) and five replications. The hydroponic system used was the NFT. For nutrition, Hidrogood Fert ${ }^{\circledR}$ solution (Compound + Calcium + Iron) was applied. At the 40th day after sowing, green and dry leaf biomass, green stem biomass, leaf area, leaf area index and productivity were analyzed. After that, the variance analysis was performed by the F-test for $5 \%$ of probability and the Scott-Knott test for comparison of the averages. The high temperatures caused very small growth in the stem of the Simpson cultivars, independent of the irrigation regime used. Besides the highlight of the American cultivars, the other cultivars presented satisfactory performance in the climatic conditions of Lagoa Seca / PB.

Keywords: NFT, Lactuca sativa, semiarid.

Abbreviations: DAS_Days after sowing, AF_estimated leaf area, PF_leaf dry mass, PD_discs' dry mass, and AD_leaf discs area.

\section{Introduction}

For great part of the Brazilian Northeast, as well for regions that present pluviometric irregularities, the cultivation of vegetables without irrigation has proved to be impracticable. Thus, in order to make irrigated agriculture feasible in view of the growing food demand in the context of water scarcity, it is fundamental to redefine practices that do not compromise environmental sustainability.

With the expectation that the world population will double by 2025, the demand for the natural resources rational use and especially water will be a great concern (Verdade et al., 2006; Soares et al., 2010; Santos et al., 2010). Indiscriminate use and scarcity in the future suggest the use of more intensive production systems that reduce water consumption by crops (Stanguellini, 2003; Sousa et al., 2011a).

In this sense, the hydroponic cultivation has been spread rapidly throughout the country thanks to some factors, such as the saving of water use, the best final price of the product, the greater demand for higher quality products and the greater diffusion of technology (Cometti at al., 2008, Flôres et al., 2016). Hydroponics is an alternative technique of growing plants in nutrient solution in the absence or presence of natural or artificial substrates. The NFT technique promotes recirculation of the nutrient solution and enables the greater efficiency of water use (Montezano et al., 2002). In addition, it enables production through the whole year, facilitates the crop management, improves the inputs use, partially controls adverse environmental conditions, and the final product is much cleaner giving the consumer greater convenience in cleaning the product before of consumption (Lopes et al., 2002).

Among the most widespread crops between hydroponic producers is the lettuce (Lactuca sativa L.), probably due to its pioneering nature as a hydroponic crop in the country, as well as its been a crop that has the easiest management and the shortest cycle (45 to 60 days) so ensuring the faster return on equity.

It is the most important greenery in Brazil because it is included in human food, both for taste, low cost and nutritional quality, as well as for the source of vitamins, minerals and fibers (Magalhães et al., 2010). The most recent 
data indicate that around 1.27 million of ton.year-1 of lettuce were produced in Brazil, and the state of São Paulo contributed $16 \%$ of the national production (IEA, 2016).

This crop is also very sensitive to climatic conditions. Factors such as photoperiod, light intensity, carbon dioxide concentration, and particularly temperature, have major influences on the growth and development of the lettuce plant (Souza et al., 2013b).

In the market, many cultivars are already adapted to protected cultivation, while there are no recommendations, mainly for hydroponic cultivation (Gualberto et al., 2002). The absence of selected cultivars or improved cultivars for the protected environment, plus the lack of acclimatization in the growing environment, and consequently high temperature have constituted limiting factors in some regions (Oliveira et al., 2003).

Therefore, the objective of this study was to evaluate the hydroponic system, the lettuce cultivars production in different irrigation systems during the wet winter and summer of the Paraiba's cariri.

\section{Results and Discussion}

The variance analysis (ANOVA) of the variables showed a significant effect on the triple interaction (Time $x$ Irrigation $x$ Cultivar). Thus, we analyzed the unfolding of these interactions for statistical effect.

Evaluation of green stem biomass showed the highest weight (62.59 g/plant) in Simpson cultivar was cultivated at the drought time using a 30-minute irrigation system (Table 1). This weight is directly related to stem growth, which is not desired in the lettuce crop. Considering this fact, it can be verified that the Great Lakes and Cristina cultivars suffered less influence of the high temperatures, when cultivated in wet season, independent of the planting time and the irrigation system.

Same results were also found by Ferreira et al. (2009) and Flôres et al. (2016), when they verified that the Simpson cultivar showed high stem growth when they were cultivated under the climatic conditions of Rio Branco-AC and Humaitá$A M$, respectively, characterizing the precocious bolting of the lettuce. This higher stem growth of Simpson cultivar demonstrates the effect of temperature elevations and luminosity in the cultivation place, once the physiological disturbances become more frequent in those conditions and decrease the yield of most lettuce cultivars (Fu et al., 2012).

Table 2 shows the interaction between the treatments for the green phytomass of the leaves, where it is verified that the American cultivars presented the highest average of this variable (159.92 g/plant) among the others, when it was cultivated in the wet season with 15 minute irrigation system (Table 2). If the option is to cultivate in the drought period, the American cultivar produced average of 128.46 and 134.16 $\mathrm{g} /$ plant under irrigation systems of 30 and 45 minutes, respectively. The cultivar Cristina also stands out with averages of 120.81 and $127.38 \mathrm{~g} /$ plant in the irrigation systems of 30 and 45 minutes, respectively. It is worth mentioning that Great Lakes cultivar belonging to the same group of American cultivar, presented the worst result, independent of the growing season and the irrigation system used.
Likewise, some studies have shown that certain lettuce cultivars are more adapted to high temperature conditions. Souza et al. (2013) observed two types of American cultivars (Teresa and Delícia) with satisfactory development, when cultivated under adverse temperature conditions, corroborating with our results. Blind and Silva Filho (2015) also observed a good performance of the American Gloriosa, Havassu, Ironwood, Kaiser and Winslon cultivars, likewise Flôres et al. (2016) who reported for the Regina and Repolhuda Todo Ano cultivars under high temperatures conditions.

Regarding the leaf dry matter, the best results ( 7.26 and 6.96 $\mathrm{g} /$ plant) were obtained in the Cristina cultivars, when it was cultivated during the dry season and using irrigation system of 30 minutes and 45 minutes, respectively (Table 3 ). Also note the average of the American cultivars ( $6.38 \mathrm{~g} / \mathrm{plant})$, when it was produced in the drought and in 45 minutes irrigation system.

Silva and Queiroz (2013) observed that the dry matter mass of the aerial part of the curly lettuce type of cultivars (Mônica and Isabela) is similar to those of the American type (Kaiser and Tainá) and the smooth type (Elizabeth) in a protected environment in the municipality of Juazeiro-BA. However, the averages of these cultivars were not higher than those found in the cultivars highlighted in this study (Cristina and Americana).

The leaf area averages found in this study indicates that the American cultivar stood out from the others when it was cultivated in the rainy season and in a 15 minutes irrigation system, since it obtained an area of $5,514.20 \mathrm{~cm}^{2} /$ plant (Table 4).

Similar results were observed by evaluating the effect of growing seasons on lettuce cultivars (Marisa, Verônica, Veneza Roxa and Vera). It was verified that the plants cultivated in the winter presented larger leaf area averages than those produced in the summer (Feltrim et al., 2009). Luz et al. (2008) evaluated the energy consumption in hydroponic lettuce production system (Regina cv.) with three intervals between irrigations (15, 30 and 45 minutes) and they did not find the significant effect of these irrigation intervals on the leaf area of this crop.

In addition to adapting to high temperatures and cultivation systems, the American cultivars stood out because they presented more internal leaves with yellow or white color, imbricated and crunchy, which are favourable characteristics for better processing, besides presenting better post-harvest conservation, resistance to transportation and handling. These characteristics allow it to be used both natural, and in the industry of minimum processing and by fast food chains (Yuri et al., 2002; Henz and Suinaga, 2009).

When the leaf area index average was observed, we noted that the American cultivars stood out from the others and presented a higher mean again $\left(7.35 \mathrm{~cm}^{2} . \mathrm{cm}^{-2}\right)$ for this variable (Table 5). This superior development comparing with the other cultivars may be related to the genetic improvement of the crop, which makes some cultivars more tolerant to high temperatures, as verified by Feltrim et al. (2005). 
Table 1. Effect of treatments on the green stem biomass (FVC) of lettuce cultivars produced in a hydroponic system at different planting times and irrigation system.

\begin{tabular}{|c|c|c|c|c|c|c|}
\hline \multirow{4}{*}{ Cultivar } & \multicolumn{6}{|c|}{ Planting Time } \\
\hline & \multicolumn{3}{|l|}{ Dry } & \multicolumn{3}{|c|}{ Wet (Rainy) } \\
\hline & \multicolumn{3}{|c|}{ Irrigation System } & \multicolumn{3}{|c|}{ Irrigation System } \\
\hline & $15 \mathrm{~min}$ & $30 \mathrm{~min}$ & $45 \mathrm{~min}$ & $15 \mathrm{~min}$ & $30 \mathrm{~min}$ & $45 \mathrm{~min}$ \\
\hline Elba & 24.77 Ba $\alpha$ & $24.17 \mathrm{Ca} \alpha$ & $19.83 \mathrm{Ca} \alpha$ & $15.78 \mathrm{Cb} \alpha$ & $14.37 \mathrm{Cb} \alpha$ & $17.82 \mathrm{Ca} \alpha$ \\
\hline G. Lakes & 10.31 Da $\alpha$ & $8.94 \mathrm{Da} \alpha$ & 8.68 Da $\alpha$ & 7,42 Da $\alpha$ & $8.45 \mathrm{Da} \alpha$ & $6.31 \mathrm{Da} \alpha$ \\
\hline M. Rose & 16.95 Ca $\alpha$ & 19.14 Ca $\alpha$ & $20.42 \mathrm{Ca} \alpha$ & $20.95 \mathrm{Ca} \alpha$ & 19.12 Ca $\alpha$ & 17.12 Сa \\
\hline Simpson & $37.65 \mathrm{Ab} \beta$ & 62.59 Аа $\alpha$ & 59.97 Ааa & 58.07 Аa $\alpha$ & $43.69 \mathrm{Ab} \beta$ & $48.39 \mathrm{Ab} \beta$ \\
\hline American & $22.05 \mathrm{Bb} \beta$ & $36.21 \mathrm{Ba \alpha}$ & 30.45 Ва $\alpha$ & $33.85 \mathrm{Ba} \alpha$ & $32.62 \mathrm{Ba \alpha}$ & $30.28 \mathrm{Ba} \alpha$ \\
\hline Cristina & 16.61 Ca $\alpha$ & $21.85 \mathrm{Ca} \alpha$ & $22.51 \mathrm{Ca} \alpha$ & $18.95 \mathrm{Ca} \alpha$ & 17.49 Са $\alpha$ & $17.58 \mathrm{Ca} \alpha$ \\
\hline
\end{tabular}

Distinct characters such as capital letters in the columns (unfolding of cultivar within each planting time level and irrigation), lowercase letter in the rows (unfolding of planting time within each cultivar level and irrigation) and Greek letter in the row (unfolding of irrigation within each planting time level and cultivar), differ themselves by Scott-Knott's test at $5 \%$ probability.

Table 2. Effect of treatments on the green leaf biomass (FVF) of lettuce cultivars produced in a hydroponic system at different planting times and irrigation system.

\begin{tabular}{|c|c|c|c|c|c|c|}
\hline \multirow{4}{*}{ Cultivar } & \multicolumn{6}{|c|}{ Planting Time } \\
\hline & \multicolumn{3}{|l|}{ Dry } & \multicolumn{3}{|c|}{ Wet (Rainy) } \\
\hline & \multicolumn{3}{|c|}{ Irrigation System } & \multicolumn{3}{|c|}{ Irrigation System } \\
\hline & $15 \mathrm{~min}$ & $30 \mathrm{~min}$ & $45 \mathrm{~min}$ & $15 \mathrm{~min}$ & $30 \mathrm{~min}$ & $45 \mathrm{~min}$ \\
\hline Elba & 102.33 Aa $\alpha$ & 88.66 Ba $\alpha$ & $81.05 \mathrm{Ca} \alpha$ & $68.76 \mathrm{Db} \alpha$ & $64.10 \mathrm{Bb} \alpha$ & $68.57 \mathrm{Ca} \alpha$ \\
\hline G. Lakes & 79.70 Ва $\alpha$ & 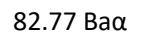 & 68.65 Ca $\alpha$ & 60.03 Da $\alpha$ & $70.08 \mathrm{Ba \alpha}$ & $48.00 \mathrm{Db} \alpha$ \\
\hline M. Rose & 86.63 Ва $\alpha$ & $95.15 \mathrm{Ba} \alpha$ & 101.47 Ва $\alpha$ & $77.21 \mathrm{Da} \alpha$ & 83.89 Aa $\alpha$ & $74.16 \mathrm{Cb} \alpha$ \\
\hline Simpson & $71.13 \mathrm{Bb} \beta$ & 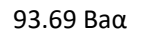 & $98.61 \mathrm{Ba \alpha}$ & 92.06 Сa $\alpha$ & 83.92 Aa $\alpha$ & 90.50 Са $\alpha$ \\
\hline American & $108.16 \mathrm{Ab} \beta$ & 128.46 Ааa & 134.16 Ааa & 159.92 Aa $\alpha$ & $90.22 \mathrm{Abp}$ & $132.81 \mathrm{Aa} \beta$ \\
\hline Cristina & $87.16 \mathrm{Bb} \beta$ & 120.81 Aa $\alpha$ & 127.38 Aa $\alpha$ & 113.85 Ba $\alpha$ & $99.97 \mathrm{Ab \alpha}$ & 106.94 Bba \\
\hline
\end{tabular}

Distinct characters such as capital letters in the columns (unfolding of cultivar with in each planting time level and irrigation), lowercase letter in the rows (unfolding of planting time within each cultivar level and irrigation) and Greek letter in the row (unfolding of irrigation within each planting time level and cultivar), differ themselves by Scott-Knott's test at $5 \%$ probability.

Table 3. Effect of treatments on the dry leaf biomass (FSF) of lettuce cultivars produced in a hydroponic system at different planting times and irrigation system.

\begin{tabular}{|c|c|c|c|c|c|c|}
\hline Cultivar & \multicolumn{6}{|c|}{ Planting Time } \\
\hline & \multicolumn{2}{|l|}{ Dry } & \multicolumn{2}{|c|}{ Wet (Rainy) } & & \\
\hline & \multicolumn{2}{|c|}{ Irrigation System } & \multicolumn{3}{|c|}{ Irrigation System } & \\
\hline & $15 \mathrm{~min}$ & $30 \mathrm{~min}$ & $45 \mathrm{~min}$ & $15 \mathrm{~min}$ & $30 \mathrm{~min}$ & $45 \mathrm{~min}$ \\
\hline Elba & $3.11 \mathrm{Ba \alpha}$ & $4.02 \mathrm{Ba} \alpha$ & 3.63 Ca $\alpha$ & $1.40 \mathrm{Db} \alpha$ & $2.54 \mathrm{Bb} \alpha$ & $2.12 \mathrm{Db} \alpha$ \\
\hline G. Lakes & $2.96 \mathrm{Ba} \beta$ & 4.70 Ba $\alpha$ & $3.69 \mathrm{Ca} \beta$ & $1.72 \mathrm{Db} \beta$ & $2.89 \mathrm{Bb} \alpha$ & $1.85 \mathrm{Db} \beta$ \\
\hline M. Rose & $3.69 \mathrm{Ba} \beta$ & 4.64 Ba & 5.19 Ba $\alpha$ & $2.47 \mathrm{Cb} \alpha$ & $3.52 \mathrm{Bb} \alpha$ & $3.14 \mathrm{Cb} \alpha$ \\
\hline Simpson & 3.17 Ваß & 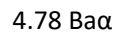 & 5.27 Ba $\alpha$ & $2.65 \mathrm{Ca} \beta$ & 4.28 Aa $\alpha$ & $3.14 \mathrm{Cb} \beta$ \\
\hline American & $4.63 \mathrm{Ab \beta}$ & $5.66 \mathrm{Ba \alpha}$ & 6.38 Aa $\alpha$ & 5.72 Aa $\alpha$ & $4.08 \mathrm{Ab} \beta$ & $5.23 \mathrm{Ab} \alpha$ \\
\hline Cristina & $3.32 \mathrm{Ba} \beta$ & 7.26 Aa $\alpha$ & 6.96 Aa $\alpha$ & 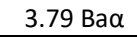 & $4.54 \mathrm{Ab} \alpha$ & $3.75 \mathrm{Bb} \alpha$ \\
\hline
\end{tabular}

Distinct characters such as capital letters in the columns (unfolding of cultivar within each planting time level and irrigation), lowercase letter in the rows (unfolding of pla nting time within each cultivar level and irrigation) and Greek letter in the row (unfolding of irrigation within each planting time level and cultivar), differ themselves by Scott-Knott's test at $5 \%$ probability.

Table 4. Effect of treatments interaction on the leaf area (AF) of lettuce cultivars produced in a hydroponic system at different planting times and irrigation system.

\begin{tabular}{|c|c|c|c|c|c|c|}
\hline \multirow{4}{*}{ Cultivar } & \multicolumn{6}{|c|}{ Planting Time } \\
\hline & \multicolumn{3}{|l|}{ Dry } & \multicolumn{3}{|l|}{ Wet (Rainy) } \\
\hline & Irrigation Sys & & & Irrigation System & & \\
\hline & $15 \mathrm{~min}$ & $30 \mathrm{~min}$ & $45 \mathrm{~min}$ & $15 \mathrm{~min}$ & $30 \mathrm{~min}$ & $45 \mathrm{~min}$ \\
\hline Elba & 1959.53 Aa $\alpha$ & 3166.26 Aa $\alpha$ & 2678.84 Ba $\alpha$ & $1620.10 \mathrm{Da} \alpha$ & $2581.17 \mathrm{Ba} \alpha$ & $2232.13 \mathrm{CaO}$ \\
\hline G. Lakes & 1868.45 Aa $\alpha$ & 1870.11 Aa $\alpha$ & 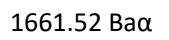 & 1452.01 Daa & 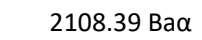 & 1504.77 Caa \\
\hline M. Rose & 2306.75 Aa $\alpha$ & 3190.07 Aa $\alpha$ & 3512.94 Aa $\alpha$ & 2268.49 Ca $\alpha$ & $2725.60 \mathrm{Ba \alpha}$ & $1895.59 \mathrm{Cbo}$ \\
\hline Simpson & 1951.79 Аa $\alpha$ & 3039.49 Aba & 2651.89 Ba & $3025.61 \mathrm{Ca} \beta$ & 4466.67 Аа $\alpha$ & $3172.97 \mathrm{Ba} \beta$ \\
\hline American & $927.92 \mathrm{Ab} \beta$ & 2599.61 Aa & $2380.15 \mathrm{Bb} \alpha$ & 5514.20 Аa $\alpha$ & $3687.51 \mathrm{Aa} \beta$ & $4662.04 \mathrm{Aao}$ \\
\hline Cristina & 1936.46 Ab $\beta$ & 3258.52 Aa $\alpha$ & 3677.20 Aa $\alpha$ & $3872.46 \mathrm{Ba} \alpha$ & 3264.12 Aa $\alpha$ & 3306.75 Bao \\
\hline
\end{tabular}

Distinct characters such as capital letters in the columns (unfolding of cultivar within each planting time level and irrigation), lowercase letter in the rows (unfolding of planting time within each cultivar level and irrigation) and Greek letter in the row (unfolding of irrigation within each planting time level and cultivar), differ themselves by Scott-Knott's test at $5 \%$ probability. 
Table 5. Effect of treatments on the leaf area index (IAF) of lettuce cultivars produced in a hydroponic system at different planting times and irrigation system.

\begin{tabular}{|c|c|c|c|c|c|c|}
\hline \multirow{4}{*}{ Cultivar } & \multicolumn{6}{|c|}{ Planting Time } \\
\hline & \multicolumn{2}{|c|}{ Dry } & & \multicolumn{3}{|l|}{ Wet (Rainy) } \\
\hline & \multicolumn{2}{|c|}{ Irrigation System } & & \multicolumn{2}{|l|}{ Irrigation System } & \\
\hline & $15 \mathrm{~min}$ & $30 \mathrm{~min}$ & $45 \mathrm{~min}$ & $15 \mathrm{~min}$ & $30 \mathrm{~min}$ & $45 \mathrm{~min}$ \\
\hline Elba & $2.61 \mathrm{Aa} \alpha$ & $4.22 \mathrm{Aa} \alpha$ & $3.57 \mathrm{Ba \alpha}$ & $2.16 \mathrm{Da} \alpha$ & $3.44 \mathrm{Ba} \alpha$ & $2.98 \mathrm{Ca} \alpha$ \\
\hline G. Lakes & 2.49 Aa $\alpha$ & $2.49 \mathrm{Aa} \alpha$ & $2.22 \mathrm{Ba} \alpha$ & 1.94 Da $\alpha$ & $2.81 \mathrm{Ba} \alpha$ & $2.01 \mathrm{Ca} \alpha$ \\
\hline M. Rose & 3.08 Aa $\alpha$ & 4.25 Aa $\alpha$ & 4.68 Aa $\alpha$ & 3.03 Ca $\alpha$ & $3.64 \mathrm{Ba \alpha}$ & $2.53 \mathrm{Cb} \alpha$ \\
\hline Simpson & 2.60 Aa $\alpha$ & $4.05 \mathrm{Ab} \alpha$ & $3.54 \mathrm{Ba \alpha}$ & $4.03 \mathrm{Ca} \beta$ & 5.96 Аa $\alpha$ & $4.23 \mathrm{Ba} \beta$ \\
\hline American & $1.24 \mathrm{Ab} \beta$ & 3.46 Aa $\alpha$ & $3.17 \mathrm{Bb} \alpha$ & 7.35 Aa $\alpha$ & $4.91 \mathrm{Aa} \beta$ & $6.22 \mathrm{Aa} \alpha$ \\
\hline Cristina & $2.58 \mathrm{Ab} \beta$ & 4.34 Aa $\alpha$ & 4.90 Aa $\alpha$ & 5.16 Ва $\alpha$ & 4.35 Aa $\alpha$ & 4.41 Ва $\alpha$ \\
\hline
\end{tabular}

Distinct characters such as capital letters in the columns (unfolding of cultivar within each planting time level and irrigation), lowercase letter in the rows (unfolding of planting time within each cultivar level and irrigation) and Greek letter in the row (unfolding of irrigation within each planting time level and cultivar), differ themselves by Scott-Knott's test at $5 \%$ probability.

Table 6. Effects of treatments on the productivity of the plant aerial part (PRO) of lettuce cultivars produced in a hydroponic system at different planting times and irrigation system.

\begin{tabular}{|c|c|c|c|c|c|c|}
\hline \multirow{4}{*}{ Cultivar } & \multicolumn{6}{|c|}{ Planting Time } \\
\hline & \multicolumn{3}{|l|}{ Dry } & \multicolumn{3}{|c|}{ Wet (Rainy) } \\
\hline & \multicolumn{3}{|c|}{ Irrigation System } & \multicolumn{3}{|c|}{ Irrigation System } \\
\hline & $15 \mathrm{~min}$ & $30 \mathrm{~min}$ & $45 \mathrm{~min}$ & $15 \mathrm{~min}$ & $30 \mathrm{~min}$ & $45 \mathrm{~min}$ \\
\hline Elba & 20336.0 Aa $\alpha$ & 18052.8 Ba $\alpha$ & 16141.8 Ba $\alpha$ & $13525.8 \mathrm{Cb} \alpha$ & $12555.2 \mathrm{Bb} \alpha$ & 13822.7 Ca $\alpha$ \\
\hline G. Lagos & 14401.9 Ва $\alpha$ & 14673.3 Ва $\alpha$ & $12372.5 \mathrm{Ca} \alpha$ & 10791.7 Da & 12564.2 Ba $\alpha$ & 8690.9 Da $\alpha$ \\
\hline M. Rosa & 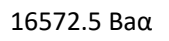 & 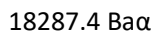 & 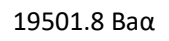 & $15704.3 \mathrm{Ca} \alpha$ & 16483.2 Aa $\alpha$ & $14604.2 \mathrm{Cb} \alpha$ \\
\hline Simpson & $17405.8 \mathrm{Bb} \beta$ & 25003.8 Аа $\alpha$ & 25371.5 Aa $\alpha$ & 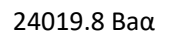 & 20419.5 Aba & 22223.0 Ba $\alpha$ \\
\hline Americana & 20833.9 Ab $\beta$ & 26347.8 Aa $\alpha$ & 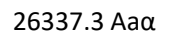 & 31003.2 Aa $\alpha$ & 19653.8 Aby & 26094.4 Aaß \\
\hline Cristina & $16603.5 \mathrm{Bb} \beta$ & 22825.9 Aа $\alpha$ & 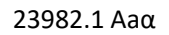 & $21247.0 \mathrm{Ba} \alpha$ & 18793.3 Aba & $19924.5 \mathrm{Bb} \alpha$ \\
\hline
\end{tabular}

Distinct characters such as capital letters in the columns (unfolding of cultivar within each planting time level and irrigation), lowercase letter in the rows (unfolding of planting time within each cultivar level and irrigation) and Greek letter in the row (unfolding of irrigation within each planting time level and cultivar), differ themselves by Scott-Knott's test at $5 \%$ probability.

However, in spite of having presented index of leaf area superior to the other cultivars, its average was inferior to those obtained by Peres et al. (2016) with Elisa $\left(22.8 \mathrm{~cm}^{2} . \mathrm{cm}^{-2}\right)$, Florence $\left(17.7 \mathrm{~cm}^{2} . \mathrm{cm}^{-2}\right)$ and Veronica $\left(18.7 \mathrm{~cm}^{2} . \mathrm{cm}^{-2}\right)$ cultivars which grown in a plastic greenhouse in the Araras-SP region.

\section{Green phytomass and productivity}

In the same way observed in the leaf area and leaf area index the green phytomass of the leaves of the American cultivars also stood out with the highest average productivity referring to the aerial part $\left(31,003.2 \mathrm{~kg} \cdot \mathrm{ha}^{-1}\right)$, when it was cultivated in the rainy season and under 15 minute irrigation system. It is important to note that American cultivars are cabbage crested kind (head form), which is not favorable factor. There is another cultivar (Great Lakes) with the same characteristics, but this presented productivity below the others (Table 6).

These results resemble those found by Oliveira et al. (2016) with the Delicia American cultivars as they observed a productivity average of $33,100.0 \mathrm{kgha}^{-1}$ when they studied the lettuce cultivars development (Delicia Americana, Irene, Legacy, Mauren, and Kaiser) in the climatic conditions of Eastern Amazon (Brazil).

Although the other cultivars presented worse performance than the American cultivar, it can be verified that they showed satisfactory performance when compared to other authors works, such as Simpson and Mimosa Rubi cultivars (Ferreira et al., 2013), Great Lakes and Elba (Flôres et al., 2016) and Cristina (Silva et al., 2016).

\section{Materials and Methods}

\section{Experimental site}

The work consisted of two experiments set up in 2015. The first cultivation started on 05/17/2015 (dry season) and the second on 06/20/2015 (wet season), of the State University of Paraíba (UEPB), located in the municipality of Lagoa Seca - PB (Latitude 7009'17,88"S, Longitude 3552'16,65"W and altitude of $653 \mathrm{~m})$. According to the data from the Estação Meteorológica da Empresa Estadual de Pesquisa Agropecuária da Paraíba S.A. (EMEPA) [Meteorological Station of the State Agricultural Research Company of Paraíba SA], the city has the following climatic characteristics: maximum temperature average of $26.0{ }^{\circ} \mathrm{C}$, minimum temperature average of $18.2{ }^{\circ} \mathrm{C}$, annual relative humidity average of $66 \%$, annual precipitation average of $950 \mathrm{~mm}$, annual average evapotranspiration of 1,100 $\mathrm{mm}$ and daily sunshine average of 7, 7, 6, 6, 5, 7, 7, 8, 9 and 8 hours in the months of January, February, March, April, May, July, August, September, October, November and December, respectively.

\section{Treatments and experimental design}

The experiment followed a randomized block design (five blocks) in a $2 \times 3 \times 6$ factorial scheme, where the effects of the two planting seasons (dry and wet season) were studied under three irrigation systems (15 min of irrigation and $15 \mathrm{~min}$ of rest, $30 \mathrm{~min}$ of irrigation and $15 \mathrm{~min}$ of rest, $45 \mathrm{~min}$ of irrigation and $15 \mathrm{~min}$ of rest) on six lettuce cultivars (Elba, Great Lakes, Mimosa Rose, Simpson, American, Cristina), and their possible interactions. 
The cultivars' seeds were the non-pelletized type from brands marketed in our region. The hydroponic cultivation was carried out in a chapel-type greenhouse (11 m long, $8.5 \mathrm{~m}$ wide and $3.0 \mathrm{~m}$ high) and east-west orientation. The environment was protected in the ceiling by transparent low-density polyethylene film with 150 microns of thickness and antiultraviolet additive, on the sides by shading screens (shade) with $50 \%$ of sunlight retention.

The hydroponic system used was the NFT (Laminar Nutrient Flow Technique), where the nutrient solution was distributed in the culture channels by a circulating electro-pump. In order to compose the nutrient solution of the hydroponic system, the Hidrogood Fert ${ }^{\circledR}$ product was used for leaf crops (Compost + Calcium + Iron), whose nutrient values were as follows: $\mathrm{N}$ (10), $\mathrm{P}_{2} \mathrm{O}_{5}(9), \mathrm{K}_{2} \mathrm{O}(28), \mathrm{Mg}(3.3), \mathrm{S}(4.3), \mathrm{B}(0.06), \mathrm{Cu}(0.01), \mathrm{Mo}$ (0.07), $\mathrm{Mn}(0.05), \mathrm{Zn}(0,02)$. The dilution concentrations were determined according to the manufacturer's recommendations, for $1.000 \mathrm{~L}$ of the solution: $750 \mathrm{~g}$ of Compound $+550 \mathrm{~g}$ of Calcium Nitrate $+30 \mathrm{~g}$ of Fe EDDHMA, obtaining an electrical conductivity $(E C)=1.7 \mathrm{mS}$. For $\mathrm{EC}$ correction, with each decrease of $0.3 \mathrm{mS}$ per $1,000 \mathrm{~L}, 132 \mathrm{~g}$ of Compound $+97 \mathrm{~g}$ of Calcium Nitrate $+6 \mathrm{~g}$ of Fe EDDHMA were used.

The seedlings were produced in phenolic foam cubes $(2 \times 2 \times 2$ $\mathrm{cm}$ ) previously washed with running water to remove the environmental contaminant substances and to increase the $\mathrm{pH}$, according to the manufacturer's recommendation. In each cube, one seed was sown. The sample was protected from solar rays for two days in the maternity bench, where they remained until completing one week after sowing. Over this period, the phenolic foam plates were initially irrigated only with the solution at $50 \%$ of its total concentration, aiming their adaptation to the experimental conditions, avoiding possible osmotic shock. After one week, the seedlings were transferred to the nursery bench, with nutrient solution diluted to $75 \%$, where they also remained for a week. Subsequently, the seedlings were transferred to the final bench, where they were irrigated with nutrient solution at $100 \%$ of its concentration.

The need for solution replacement was checked daily with a millimeter ruler adapted to the nutrient solution reservoir. To make the solution and also to replace it, water from public supply system was used, letting it to stand for 72 hours to allow the evaporation of the chlorine used in the treatment. The $\mathrm{pH}$ of the nutrient solution was maintained between 5.5 and 6.5 , and was monitored daily with the aid of a portable digital meter. The electrical conductivity of the solution was monitored by portable conductivity meter and maintained at $1.7 \mathrm{mS}$.

The final growing benches were represented by 8 channels made up of polypropylene, in trapezoidal form ( $4.5 \mathrm{~m}$ length each), with each bench representing an irrigation system. Their arrangement in the greenhouse was made through four support points, installed at an average height of $0.85 \mathrm{~m}$, with slope of $5.0 \%$. The spacing used in the channels perforations was $0.25 \mathrm{~m} \times 0.30 \mathrm{~m}$, representing the spacing between plants and lines, respectively. For the storage of this nutrient solution we used a reservoir with capacity of 250 liters for each bench, but they worked with only $60 \%$ of their storage capacity.

In each of the benches, the nutrient solution circulation and aeration was carried out with the help of a motor pump with $23 \mathrm{~W}$ of power, installed in drowned form and driven by an analog timer that started the circulation of the solution at 06:00 a.m., being programmed to activate and/or switch off the pump according to each irrigation system (15, 30 and 45 $\min$ ), until 6:00 p.m. During the night, the timer drived the pumping for 15 minutes at 2 hours intervals for all benches, regardless of their irrigation system.

\section{Characteristics evaluated}

At the time that the lettuce cultivars completed 40 days after sowing (DAS) in phenolic foam, the following variables were analyzed: green and dry leaf biomass (g/plant), green stem biomass (g/plant), leaf area, leaf area index and average productivity for the aerial part $\left(\mathrm{kg} \cdot \mathrm{ha}^{-1}\right)$. The aerial part, of five plants per block was taken to the greenhouse with air circulation at $65^{\circ} \mathrm{C}$ to obtain the respective dried phytomass and then weighed on precision balance $(0.01 \mathrm{~g})$.

The foliar area was determined by foliar discs methodology, which consisted of the use of discs with well-known area. Ten leaf discs were removed from ten fresh leaves, with only median veins for each block. The leaves and discs were packed in paper bags, greenhouse-dried at $65^{\circ} \mathrm{C}$ for 24 hours and then weighed separately on an analytical balance. The leaf area was estimated by the formula $A F=[(P F+P D) \times A D] / P D$, which $A F$ $=$ estimated leaf area $\left(\mathrm{cm}^{2}\right), P F=$ leaf dry mass $(\mathrm{g}), \mathrm{PD}=$ discs dry mass and $A D=$ leaf disc area. The leaf area index is an indicator of the leaf cover of the land and its consequences in the interception of light. It was estimated by the formula IAF = $A F$ / (EP*EL), which EP is the spacing between plants and $E L$, is the spacing between lines.

The variables data were submitted to analysis of variance by the $\mathrm{F}$ test at $5 \%$ of probability. The Scott-Knott test was also used to compare the averages obtained for each variable. The statistical analysis was performed in the SISVAR program (Ferreira, 2014).

\section{Conclusion}

Besides the highlight of the American cultivar, the other cultivars presented satisfactory performance in the climatic conditions of Lagoa Seca / PB.

Acknowledgments

The authors wish to thanks CNPq for the grant of the scientific fellowship and the UEPB financing through PROPESQ.

\section{References}

Blind AD and Silva Filho DF (2015) Desempenho produtivo de cultivares de alface americana na estação seca da Amazônia Central. Biosc Jou. Uberlândia, 31(2): 404-414.

Cometti NN, Matias GCS, Zonta E, Mary W, Fernandes MS (2008) Efeito da concentração da solução nutritiva no crescimento da alface em cultivo hidropônico-sistema NFT. Hortic Bras. 26 (2): 252-257.

Feltrim AL, Cecílio Filho AB, Rezende BLA, Branco RBF (2009) Produção de alface-crespa em solo e em hidroponia, no inverno e verão, em Jaboticabal-SP. Cient. 37(1) 9-15.

Feltrim AL, Cecílio Filho AB, Branco RBF, Barbosa JC, Salatiel LT

(2005) Produção de alface americana em solo e em 
hidroponia, no inverno e verão, em Jaboticabal, SP. Rev Bras Eng Agríc Ambi. 9(3):505-509.

Ferreira DF (2014) Sisvar: A guide for its bootstrap procedures in multiple comparisons. Ciênc e Agrotec. 3(1): 109-112.

Ferreira LL, Aniceto RR, Montenegro INA, Ribeiro TS, Almeida DG, Porto VCN (2013) Comportamento de variedades de alface na semeadura de março no município de Areia-PB. Scie Ple. 9(4):1-7.

Ferreira RLF, Araújo Neto SE, Silva SshootS, Abud EA, Rezende MIFL, Kusdra JF (2009) Combinações entre cultivares, ambientes, preparo e cobertura do solo em características agronômicas de alface. Hortic Bras, Brasília, 27(3): 383-388.

Flôres JÁ, Santos, LAC, Silva, DMP, Oliveira IA, Pereira CE (2016) Desempenho agronômico de cultivares de alface em casa de vegetação no município de Humaitá, AM. Revista Ciências Agroambientais. 14(2):113-116.

Fu, W, Li P, Wu Y (2012) Effects of different light intensities on chlorophyll fluorescence characteristics and yield in lettuce. Scie Hortic. Amsterdam 135(1):45-51.

Gualberto R, Oliveira PSR, Guimarães AM (2002) Adaptabilidade e estabilidade fenotípica de diversas cultivares de alface do grupo crespa, em cultivo hidropônico. Hortic Bras. Brasília, 20 (1): 7-11.

Henz GP, Suinaga F (2009) Tipos de alface cultivados no Brasil. Brasília, Embrapa Hortaliças.. (Comunicado Técnico, 75), 7p.

IEA - Instituto de Economia Agrícola, 2016 [viewed 05 September 2016]. A produção da Agropecuária Paulista: considerações frente à anomalia climática [online]. Available from: http://www.iea.sp.gov.br/out/.

Luz GL, Medeiros SLP, Manfron PA, Borcioni E, Müller L, Amaral $A D$, Morais KP (2008) Consumo de energia elétrica e produção de alface hidropônica com três intervalos entre Irrigações. Ciênc Ru. Santa Maria. 38(3): 815-818.

Magalhães AG Menezes D, Resende LV, Bezerra Neto E (2010) Desempenho de cultivares de alface em cultivo hidropônico sob dois níveis de condutividade elétrica. Hortic Bras. Brasilia. 28(1): 316-320.

Ohse, S.; Dourado-Neto D, Manfron PA, Santos OS (2001) Qualidade de cultivares de alface produzidos em hidroponia. Sci Agri. Piracicaba. 58(1): 181-185.

Oliveira, CEP, Luz JMQ, Martins ST, Diniz KA, Carlis GC, Silva AM (2003) Produção de cultivares de alface em sistema hidropônico com perfis parciais ou totalmente pintados de branco. Hortica Bras. Brasília. 21(2): 1-4.

Paz, VPS, Teodoro REF, Mendonça FC (2000) Recursos hídricos, agricultura irrigada e meio ambiente. Rev Bras de Eng Agríc e Ambi. Campina Grande. 4(3): 465-473.

Peres JG, Boschi RS, Souza CF, Mendonça TG (2016) Produtividade da água para seleção de cultivares de alface. Ciênc Tec e Amb. Santa Maria. 3(1): 59-65.

Rodrigues LRF (2002) Técnicas de cultivo hidropônico e de controle ambiental no manejo de pragas, doenças e nutrição vegetal em ambiente protegido. 1.ed. Jaboticabal: FUNEP, $762 p$.

Santos AN, Soares TM, Silva EFF, Silva DJR, Montenegro, AAA (2010) Cultivo hidropônico de alface com água salobra subterrânea e rejeito da dessalinização em Ibimirim, PE. Rev bras eng agríc e amb, Campina Grande. 14(9): 961-969.

Silva IVM, Dantas MV, Costa CC, Sarmento JJA, Lopes KP. 2016. Influência da população de plantas sob o crescimento e produção orgânica de alface no Sertão paraibano. Rev Verd de Agro e Desenv Sust. Rio de Janeiro. 11(2): 55-59.

Silva VD, Queiroz SOP (2013) Manejo de água para produção de alface em ambiente protegido. Irri. Botucatu. 18(1): 184199.

Sousa AEC, Gheyi HR, Correia KG, Soares FAL, Nobre RG (2011)a Crescimento e consumo hídrico de pinhão manso sob estresse salino e doses de fósforo. Rev Ciênc Agron, Fortaleza. 42(2):310-318.

Souza AL, Seabra Júnior S, Diamante MS, Souza LHC, Nunes MCM (2013)b Comportamento de cultivares de alface americana sob clima tropical. Rev Caat. Mossoró. 26(4):123129.

Soares TM, Sergio ND, Silva EFF, Jorge CA (2010) Combinação de águas doce e salobra para a produção de alface hidropônica. Rev bras eng agríc e amb, Campina Grande. 14(7):705-714..

Yuri JE, Souza RJ de, Freitas SAC de, Rodrigues Júnior JC, Mota JH (2002) Comportamento de cultivares de alface tipo americana em Boa Esperança. Hort Bras. Brasília. 20(1): 229232. 